\title{
Failure of postpartum lactogenesis due to isolated prolactin deficiency
}

\author{
Bridget M. Akel ${ }^{1}$, Barbara L. Feuerstein ${ }^{1}$, Jayne R. Charlamb², Marisa E. Desimone*1 \\ ${ }^{1}$ Internal Medicine, State University of New York at Upstate Medical University, Syracuse, NY, USA \\ ${ }^{2}$ Obstetrics and Gynecology, State University of New York at Upstate Medical University, Syracuse, NY, USA
}

Received: November 5, 2015

Accepted: December 21, 2015 Online Published: December 29, 2015

DOI: $10.5430 /$ crim.v3n1p43

URL: http://dx.doi.org/10.5430/crim.v3n1p43

\begin{abstract}
Objective: To review a case of a postpartum female with lactation failure due to isolated prolactin deficiency.

Methods: We describe the presentation of isolated prolactin deficiency, found during the evaluation of a postpartum woman with absence of postpartum lactogenesis.

Results: A 31-year-old G1P1 female five weeks post-partum presented for evaluation of lactation failure. She had an uncomplicated pregnancy and delivery, with no retained placental fragments. The patient was unable to lactate despite regular breast stimulation through early and regular infant latch and subsequent bilateral breast pumping. The patient had a history of Hashimoto's thyroiditis, but was otherwise healthy. There was no history of alcohol abuse or breast disease. A prolactin level measured after a session of breast pumping was $12.4 \mathrm{ng} / \mathrm{ml}$ (reference range 122-370 ng/ml). Evaluation of other pituitary hormones was normal. An MRI of the pituitary was unremarkable.

Conclusion: Isolated prolactin deficiency is a rare disorder, presenting postpartum with lack of breast milk production. The cause of this condition is unclear, but may be related to autoimmune destruction of lactotrophs in some patients. In the future, treatment with recombinant human prolactin may be used to treat this rare disorder.
\end{abstract}

Key Words: Lactation insufficiency, Prolactin deficiency, Breastfeeding

\section{INTRODUCTION}

There are multiple benefits of breastfeeding for both mother and infant, including a reduction in the risk of infection, autoimmune conditions, and obesity in the infant as well as a decrease in the risk of certain cancers in the mother such as breast and ovarian cancer. ${ }^{[1]}$ The American Academy of Pediatrics recommends that infants are exclusively breastfed for approximately six months, with continued breastfeeding along with the addition of complementary foods for one year or longer. In recent decades, promotion and support of breastfeeding in the United States has grown substantially and breastfeeding rates have increased significantly. ${ }^{[2]}$

Lactation requires high concentrations of prolactin. Prolactin has direct actions on the mammary gland through the various stages of alveolar proliferation, lactogenesis I, II, and the maintenance of established milk secretion (lactogenesis III). ${ }^{[3,4]}$ The only known presenting symptom of prolactin deficiency is failure of lactation in the postpartum period in females. Most often prolactin deficiency occurs in the setting of other anterior pituitary hormone deficiencies. ${ }^{[5]}$ There have been few case reports of isolated prolactin deficiency in the literature. ${ }^{[6,7]}$ In the majority of these cases there was

\footnotetext{
*Correspondence: Marisa E. Desimone; Email: desimoma@upstate.edu; Address: Division of Endocrinology, Diabetes and Metabolism, Department of Medicine, SUNY Upstate Medical University, 3229 East Genesee Street, Syracuse, NY 13214, USA.
} 
spontaneous conception, with normal pregnancy, and the diagnosis was made after failure of lactation. ${ }^{[7]}$ In this case report we discuss a patient who, despite interest and multiple attempts at lactation, was unable to produce breastmilk in the postpartum period. This resulted in a significant amount of emotional distress for our patient. She was identified as having isolated prolactin deficiency.

\section{Case presentation}

A 31-year-old G1P1 female presented at five weeks postpartum for evaluation of lactation failure. She had no complications during the pregnancy or at delivery. The labor was augmented by oxytocin with a duration of 6 hours, resulting in a vaginal delivery of healthy baby girl (5 lbs $13 \mathrm{oz}$ ). There was no excessive bleeding. Immediately following delivery the infant was placed with the mother. The infant latched well and the patient noted uterine contractions during breastfeeding sessions. At this time and continuing over the next few weeks, despite the infant latching well on a regular basis, there was no colostrum or milk production. Because the patient was motivated to breastfeed, she started a trial of regular bilateral breast pumping with an electric pump every three hours for 30 minutes for two weeks with no milk or colostrum noted during expression. A prolactin level measured after a session of breast pumping was $12.4 \mathrm{ng} / \mathrm{ml}$. The expected levels of prolactin at 0-7 weeks postpartum at baseline are $13-95 \mathrm{ng} / \mathrm{ml}$ with peak $122-370 \mathrm{ng} / \mathrm{ml}$ as a result of stimulation. ${ }^{[3]}$

The patient had a history of normal sexual development with age appropriate Tanner stage development. Her menarche was at age 12 with subsequent menses at regular intervals. She had no difficulties with conception. During the first trimester she had breast size increase from C cup to a D cup. Her medical history was significant for hypothyroidism due to Hashimoto's thyroiditis diagnosed about two years prior to her pregnancy. She was maintained on a stable dose of levothyroxine of $88 \mathrm{mcg}$ and did not require an increase in dosage during her pregnancy. The patient's levothyroxine dose was increased to $150 \mathrm{mcg}$ the day before delivery. The reason for this increase was unclear, as the patient had normal TSH levels during pregnancy. Prior TSH value was 2.56 $\mu \mathrm{IU} / \mathrm{ml}$ (reference range $0.350-5.500 \mu \mathrm{IU} / \mathrm{ml}$ ) at 7 months gestation and $1.29 \mathrm{mIU} / \mathrm{L}$ (reference range $0.40-4.50 \mathrm{mIU} / \mathrm{L}$ ) at 8 months gestation. Her family history was notable for hypothyroidism in multiple members. There was no history of lactation insufficiency in her female relatives. Her only surgical history was a laparoscopic cholecystectomy.

At the time of her endocrine consultation (5 weeks postpartum) her medications included a multivitamin, iron supplement, and levothyroxine. She was also taking an herbal supplement for lactation that included fenugreek, fennel, raspberry leaf, thistle, and marshmallow. Despite her persistent efforts with frequent bilateral breast pumping with a high quality electric pump, she had no milk production.

On physical examination the patient was a well-appearing female. Her blood pressure was 102/63 $\mathrm{mmHg}$, heart rate 73 , and BMI of $24 \mathrm{~kg} / \mathrm{m}^{2}$. She had normal Tanner Stage $\mathrm{V}$ breast development with nipples everted and breasts relatively symmetric; no redness, and no nipple discharge. She was distressed over her inability to breastfeed her infant.

Review of laboratory testing and imaging studies showed the following: HCG two weeks postpartum was $40 \mathrm{mIU} / \mathrm{ml}$ and at 3 weeks postpartum was $7 \mathrm{mIU} / \mathrm{ml}$. These results, as well as an unremarkable transvaginal ultrasound performed at two weeks postpartum, excluded the possibility of retained products. ${ }^{[8]} \mathrm{TSH}$ (after taking $150 \mathrm{mcg}$ of levothyroxine for two weeks) was $1.17 \mu \mathrm{IU} / \mathrm{ml}$ (reference range 0.270-4.200 $\mu \mathrm{IU} / \mathrm{ml}$ ), at 3 weeks postpartum $0.33 \mathrm{mIU} / \mathrm{ml}$ (reference range $0.350-5.500 \mu \mathrm{IU} / \mathrm{ml})$ and at six weeks post-partum $0.03 \mathrm{mIU} / \mathrm{ml}$ (reference range 0.350-5.500 $\mu \mathrm{IU} / \mathrm{ml}$ ) with a corresponding FT4 of $1.7 \mathrm{ng} / \mathrm{dl}$ (0.8-1.8 ng/dl). IGF-1 at three weeks and six weeks post-partum were $138 \mathrm{ng} / \mathrm{ml}$ and $145 \mathrm{ng} / \mathrm{ml}$ (reference range $73-243 \mathrm{ng} / \mathrm{ml}$ ), respectively. Blood testing at 9:00 am showed ACTH $24.8 \mathrm{pg} / \mathrm{ml}$ (reference range 7.2-63.3 pg/ml) and cortisol $10.4 \mu \mathrm{g} / \mathrm{dl}$ (reference range 4.3-22.4 $\mu \mathrm{g} / \mathrm{dl}$ ). Other laboratory testing that was done at two weeks postpartum included a total testosterone of 91 $\mathrm{ng} / \mathrm{dl}$ (reference range $9-55 \mathrm{ng} / \mathrm{dl}$ ), progesterone $<0.5 \mathrm{ng} / \mathrm{ml}$ (reference range $0.1-27 \mathrm{ng} / \mathrm{ml}$ ), and prolactin $21.5 \mathrm{ng} / \mathrm{ml}$ (reference range $4.7-23.3 \mathrm{ng} / \mathrm{ml}$ ). At three weeks postpartum progesterone was $0.57 \mathrm{ng} / \mathrm{ml}(0.15-28.03 \mathrm{ng} / \mathrm{ml})$, and prolactin $12.4 \mathrm{ng} / \mathrm{ml}$ (reference range $2.8-29.2 \mathrm{ng} / \mathrm{ml}$ ). At six weeks postpartum, estradiol was $93.2 \mathrm{pg} / \mathrm{ml}$ (reference range $18.9-570.8 \mathrm{pg} / \mathrm{ml}$ ), unstimulated prolactin $0.8 \mathrm{ng} / \mathrm{ml}$ (reference range $2.8-29.2 \mathrm{ng} / \mathrm{ml}$ ), FSH $7.8 \mathrm{mIU} / \mathrm{ml}$ (reference range $1.5-33.4 \mathrm{mIU} / \mathrm{ml}$ ), $\mathrm{LH} 4.7 \mathrm{mIU} / \mathrm{ml}$ (reference range 0.5-76.3 $\mathrm{mIU} / \mathrm{ml}$ ), serum sodium $141 \mathrm{mmol} / \mathrm{L}$ (reference range $136-146 \mathrm{mmol} / \mathrm{L}$ ), and urine osmolality $876 \mathrm{mOs} / \mathrm{kg}$ $\mathrm{H}_{2} \mathrm{O}$ (reference range 50-1400 mOs/ $\mathrm{kg} \mathrm{H}_{2} \mathrm{O}$ ). An MRI of the pituitary showed normal anatomy (see Figure 1).

The diagnosis of isolated prolactin deficiency was made as no evidence of other pituitary abnormalities were found. Her levothyroxine was decreased to her previous dose of $88 \mathrm{mcg}$, as her previous dose increase was thought to be erroneous and had resulted in mild hyperthyroidism. The patient was offered a trial of metoclopramide, but she declined. The patient was informed that she would not be able to breastfeed her child with her own milk. Supplemental nursing systems (SNS) using either donor milk or artificial breastmilk substi- 
tutes were also discussed, and the patient declined these as well.

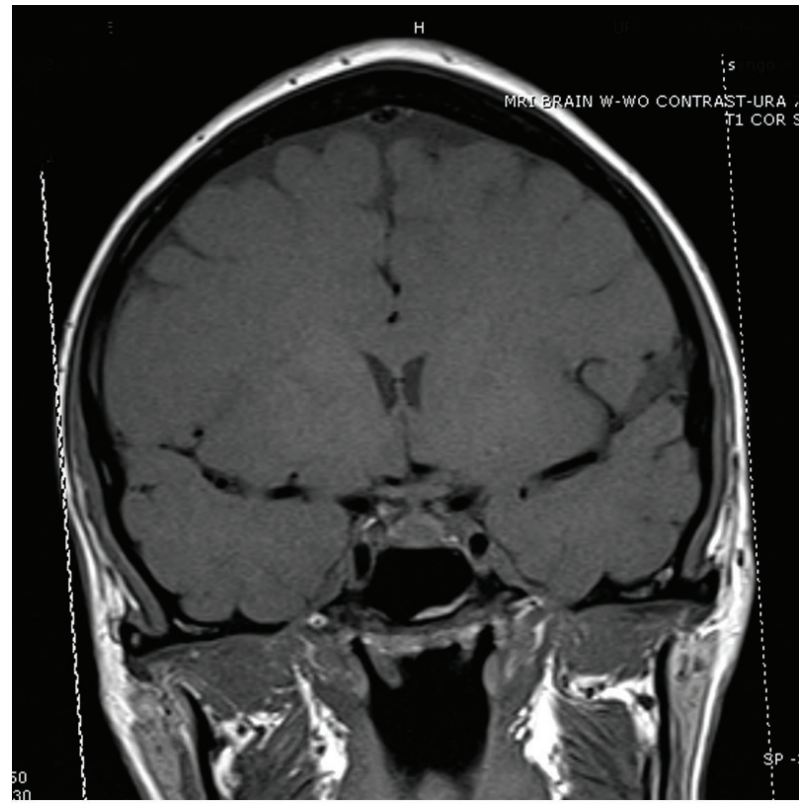

Figure 1. MRI without contrast. Normal anatomy of pituitary

\section{Discussion}

Isolated prolactin deficiency is a rare disorder, only presenting in the postpartum period due to lack of breastmilk production. Multiple hormones directly and indirectly play a role in lactation, with prolactin being one of the key factors. Metoclopramide has the potential to increase prolactin by blocking dopamine. It is unclear if this rise in prolactin would result in breastmilk production, as success would rely on functioning lactotrophs. Thyrotropin-releasing hormone (TRH) stimulation has been shown to increase prolactin levels. ${ }^{[9]}$ Stimulation with TRH and subsequent prolactin measurements could be used to test lactotroph function. In this case lactotroph failure was indicated by failure of prolactin to increase following a session of breast pumping. It is our suspicion that this patient would not have had a clinically significant response to metoclopramide or other such dopaminergic antagonists, as a paucity of prolactin throughout her pregnancy likely resulted in inadequate development of functional lactational tissue in the breast during pregnancy.

This patient did exhibit a mild iatrogenic hyperthyroidism in the postpartum period due to an erroneous increase in her levothyroxine dose. Hyperthyroidism may impair lactogenesis, possibly due to decreased prolactin levels. ${ }^{[9]}$ This was not likely a factor in this case, however, due to the short duration and mild degree of iatrogenic hyperthyroidism. Hyperthyroidism would not explain the impaired lactogenesis during the first two weeks postpartum when at least some colostrum production would be expected, as the patient was demonstrably biochemically euthyroid during this time.

There have been seven cases of isolated prolactin deficiency described in the literature. In one case ${ }^{[7]}$ a mother diagnosed postpartum with isolated prolactin deficiency was found to have antibodies to antigens in the prolactin secreting cells. Similar to our case, this patient also had Hashimoto's thyroiditis which is a common autoimmune disorder and suggests a possible predisposition to a second autoimmune condition. ${ }^{[7]}$ Prolactin antibody testing was not done in our case, but could be considered in the future. Other cases have had features suggestive of pseudohypoparathyroidism which has been reported in association with prolactin deficiency due to genetic defects in $\mathrm{G}$ proteins. ${ }^{[10]}$ Our patient did not have any calcium abnormalities or phenotypic features suggestive of pseudohypoparathyroidism.

Our patient's inability to breastfeed resulted in significant amount of emotional as well as physical stress. At this time she does not wish to pursue any additional evaluation or treatment but does have questions regarding her future planned pregnancies, most notably: Will she ever be able to breast feed? Powe et al. ${ }^{[11]}$ evaluated the use of recombinant human prolactin (r-hPRL) in five patients with prolactin deficiency, one of whom had isolated prolactin deficiency. In this patient the use of recombinant human prolactin resulted in lactation with the ability to exclusively breastfeed her infant by day 18. The administered dose of r-hPRL was $60 \mu \mathrm{g} / \mathrm{kg}$ subcutaneously every 12 hours for 28 days. In the prolactin deficient postpartum females in this small study group, the response to treatment with r-hPRL was an increase in the volume of milk produced from $3.4+/-1.6 \mathrm{ml} /$ day to $66.1+/-8.3 \mathrm{ml} /$ day. ${ }^{[11]}$

\section{Conclusion}

Isolated prolactin deficiency is a rare disorder resulting in lactation failure. The presence of Hashimoto's thyroiditis raises the possibility that this patient's prolactin deficiency represents a second autoimmune condition. The only known treatment, still experimental, involves the use of r-hPRL. 


\section{REFERENCES}

[1] Steube A, Schwarz E. The risks and benefits of infant feeding practices for women and their children. J of Peritnatol. 2010; 30: 155-162. PMid:19609306 http://dx.doi.org/10.1038/jp.2009.107

[2] Centers for disease control and prevention. Breastfeeding Report card. 2014. Available from: http://www.cdc.gov/breastfeed ing/data/reportcard.htm

[3] Hale T, Hartmann P. Textbook of Human Lactation. 1st edition. Amarillo, Texas: Hale Publishing, L.P. 2007.

[4] Lawrence RA, Lawrence RM. Breastfeeding: A Guide for the Medical Profession. 7th Edition. Elsevier Mosby: Maryland Heights, Missouri. 2011.

[5] Toledano Y, Lubetsky A, Shimon I. Acquired prolactin deficiency in patients with disorders of the hypothalamic-pituitary axis. J Endocrinol Invest. 2007; 30: 268-273. PMid:17556861 http://dx.d oi.org/10.1007/BF03346292

[6] Turkington R. Phenothiazine stimulation for prolactin reserve: the syndrome of isolated prolactin deficiency. J Clin Endocrinol Metab. 1972; 34: 246-249. http://dx.doi.org/10.1097/00006254-1 97211000-00012
[7] Iwama S, Welt C, Romero C, et al. Isolated prolactin deficiency associated with serum autoantibodies against prolactin-secreting cells J Clin Endocrinol Metab. 2013; 98: 3920-3925. PMid:23940128 http://dx.doi.org/10.1210/jc.2013-2411

[8] American Pregnancy Association. Human Chorionic Gonadotropin (HCG); The Pregnancy Hormone. Available from: http://americ anpregnancy .org/while-pregnant/hcg-levels/

[9] Snyder PJ, Jacobs LS, Utiger RD, et al. Thyroid hormone inhibition of the prolactin response to thyrotropin-releasing hormone. J of Clin Invest. 1973; 52: 2324-2329. PMid:4199418 http://dx.doi.org /10.1172/JCI107421

[10] Carlson H, Brickman A, Bottazo G. Prolactin deficiency in pseudohypoparathyroidism. N Engl J Med. 1977; 296: 140-144. PMid:401530 http://dx.doi.org/10.1056/NEJM197701202960304

[11] Powe C, Allen M, Puopolo K, et al. Recombinant human prolactin for the treatment of lactation insufficiency. Clin Endocrinol. 2010; 73: 645-653. PMid:20718766 http://dx.doi.org/10.1111/j.136 $5-2265.2010 .03850 . x$ 